\title{
Kajian Pengkompleksan Sebatian Bis-Tiourea dengan Ion Aluminium sebagai Ionofor dalam Pembangunan Sensor Ion Potensiometri
}

(Complexation Study of Bis-Thiourea Compound with Aluminium Ion as Ionophore for Development of Potentiometric Ion Sensor)

\author{
KoOK SHiH Ying, Fatimatul AKMA AwANG NGaH, SuHAila SAPARI, \\ LEE YOOK HENG \& SiTI AISHAH HASBULlAH*
}

\begin{abstract}
ABSTRAK
Sebatian terbitan tiourea telah banyak digunakan sebagai ionofor untuk merkuri, kadmium, kuprum, plumbum dan ferum (III) dalam bidang sensor kimia. Namun, penggunaan sebatian tiourea sebagai ionofor aluminium masih tidak banyak dilaporkan. Dalam kajian ini, satu sebatian bis-tiourea baharu 1,1'-[(metilazandiyil)bis(etana-2,1-diyil)]bis[3-(naftalen1-yil)tiourea] ACH telah disintesis dan dicirikan dengan menggunakan spektroskopi $1 \mathrm{H}, 13 \mathrm{C}$-resonans magnetik nukleus, spektroskopi inframerah dan spektrometri jisim. Untuk menilai dan menentusah kesesuaian sebatian ACH sebagai ionofor

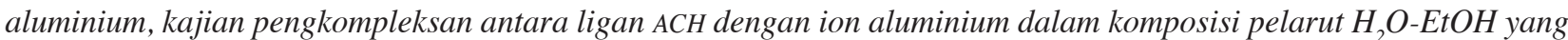
berbeza melalui kaedah spektrofluorimetri telah dijalankan. Antara lima jenis komposisi pelarut, hanya pelarut $25 \% \mathrm{H}_{2} \mathrm{O}$ $75 \%$ EtOH menunjukkan pembentukan kompleks. Nisbah stoikiometri bagi ion kompleks yang terbentuk antara ligan ACH dengan ion $\mathrm{Al}^{3+}$ ialah 3:1 dengan formula $\left[\mathrm{Al}(\mathrm{ACH})_{3}\right]^{3+}$ dan nilai $\mathrm{pK}$ yang diperoleh ialah 5.10 \pm 0.01 . Struktur ion kompleks [ACH-Al] ${ }^{3+}$ dengan stokoimetri 1:1 juga telah dioptimumkan melalui pengiraan teori fungsi ketumpatan. Kedua-dua atom sulfur daripada kumpulan berfungsi bis-tiourea didapati merupakan tapak aktif yang terlibat dalam proses pengkompleksan dan geometri separa rongga ditunjukkan pada ligan ACH untuk berkoordinat dengan ion Al ${ }^{3+}$. Nilai negatif yang rendah pada tenaga pengikatan $[\mathrm{ACH}-\mathrm{Al}]^{3+}$, iaitu $-5.560 \times 10^{6} \mathrm{~kJ} / \mathrm{mol}$ juga memaparkan kestabilan ion kompleks yang kuat. Sebagai kesimpulan, sebatian ACH adalah sesuai digunakan sebagai ionofor aluminium yang baharu dalam sensor ion potensiometri.
\end{abstract}

Kata kunci: 1,1'-[(metilazandiyil)-bis(etana-2,1-diyil)]bis[3-(naftalen-1-yil)tiourea]; kajian pengkompleksan; pencirian sebatian bis-tiourea; pengiraan teori fungsi ketumpatan

\section{ABSTRACT}

Thioure compounds have been applied as ionophores for mercury, cadmium, copper, lead, and iron(III) in the field of chemical sensor. However, thiourea compound as aluminium ionophore has not yet been sufficiently explored. In this work, a new thiourea compound, 1,1'-[(methylazanediyl)bis(ethane-2,1-diyl)]bis[3-(naphthalen-1-yl)thiourea] had been synthesized and characterized by using $1 \mathrm{H}, 13 \mathrm{C}$-nuclear magnetic resonance spectroscopy, Fourier-transform infrared spectroscopy and mass spectrometry. To assess and confirm the suitability of ACH compound as aluminum ionophore, complexation study of ACH ligand with aluminum ion in different solvent compositions of $\mathrm{H}_{2} \mathrm{O}-\mathrm{EtOH}$ via spectrofluorimetic method had been carried out. Among the five types of solvent mixtures, the study indicated that only the solvent mixture of $25 \% \mathrm{H}_{2} \mathrm{O}-75 \% \mathrm{EtOH}$ showed the formation of complex. The stoichiometric ratio formed between ACH ligand and $\mathrm{Al} \mathrm{l}^{3+} \mathrm{ions}$ was 3:1 with the formula of $\left[\mathrm{Al}(\mathrm{ACH})_{3}\right]^{3+}$ and the $\mathrm{pK}$ a value was 5.10 \pm 0.01 . The structure optimization of the complex ion $[\mathrm{ACH}-\mathrm{Al}]^{3+}$ in the ratio of 1:1 was also conducted by using the density functional theory calculation. Both of the sulfur atoms in the functional group of bis-thiourea were found to be the main active sites for the complexation process and the ACH ligand showed a partial cavity geometry to coordinate with $\mathrm{Al}^{3+}$ ion. The low negative value of the binding energy $[\mathrm{ACH}-\mathrm{Al}]^{3+},-5.560 \times 10^{6} \mathrm{~kJ} / \mathrm{mol}$ also showed that the complex ion formed was strong and stable. In conclusion, ACH compound was suitable as a new aluminum ionophore for potentiometric ion sensor.

Keywords: 1,1'-[(methylazanediyl)bis(ethane-2,1-diyl)]bis[3-(naphthalen-1-yl)thiourea]; bis-thiourea compound characterization; complexation study; density functional theory

\section{PENGENALAN}

Aluminium merupakan elemen yang penting terhadap pembangunan sosial-ekonomi manusia. Logam ini telah digunakan secara meluas dalam pelbagai sektor seperti industri, alat perkakasan, peralatan teknologi baharu, pembinaan, pengangkutan, bahan aditif makanan, ubat dan produk pembersihan persendirian (Abdullahi et al. 2017; Supian et al. 2013). Namun, kepekatan aluminium yang tinggi akan mengakibatkan ketoksikan kepada kesihatan manusia (Vallejos et al. 2014). Organisasi Kesihatan 
Dunia (WHO) melaporkan bahawa purata pengambilan aluminium dalam badan manusia adalah 3 hingga 10 mg sehari (Rana et al. 2016). Had kepekatan aluminium dalam air minuman ialah 0.20 ppm (Al-kindy et al. 2015). Selain itu, ketoksikan aluminium juga berbahaya kepada hidupan akuatik seperti menjejaskan pembiakan ikan dan pertumbuhan tumbuhan (Person et al. 2014; Poléo 1995). Justeru, pengesanannya adalah penting untuk melindungi kesihatan manusia dan alam sekitar (Tajik et al. 2013).

Sejak kebelakangan ini, permintaan untuk menghasilkan sensor ion aluminium potensiometri yang baik dalam pengesanan ion aluminium semakin meningkat atas pengendalian yang lebih senang, instrumennya yang mudah, hanya sedikit amaun sampel diperlukan dan boleh digunakan secara langsung dalam sampel. Bagi reka bentuk sensor ion potensiometri yang peka dan selektif, ionofor yang digunakan harus mengandungi penderma elektron seperti oksigen, nitrogen atau sulfur, dan disusun dalam struktur molekul yang sesuai supaya dapat berikat dengan ion yang hendak ditentukan (Siswanta et al. 2016).

Tiourea merupakan sebatian yang mempunyai kumpulan berfungsi ( $>\mathrm{N}-\mathrm{C}(\mathrm{S})-\mathrm{N}<$ ) (Saeed et al. 2014). Sebatian ini merupakan ligan yang baik atas struktur kimianya yang mempunyai atom sulfur dan nitrogen yang bersifat nukleofilik, dapat berkoordinat dengan pelbagai ion logam (Tahir et al. 2018). Sifat yang unik ini telah mendorong penggunaannya sebagai ionofor dalam bidang sensor kimia (Jumal et al. 2012). Menurut kajian lepas, sebatian terbitan tiourea telah berjaya digunakan sebagai ionofor untuk merkuri seperti 1,2-bis(N'-benzoyiltioureido)sikloheksana (Jumal et al. 2012), 4,4'-bis-(3-feniltiourea)difenilmetana dan 2-2-[10-[(E)2-(aminokarbotioyil)hidrazono]-1,4-dihidroksil-9(10H)antraseniliden]-1-hidrazinkarbatioamida (Ghanei-motlagh et al. 2014), 1-dietil-3-(4-metoksilbenzoyil)tiourea, 4-metoksil-N-(1-pirolidinkarbonotioyil)benzamida, dan 4-metoksi-N-(piperidin-1-karbanotio-yil)benzamida (Khairi 2016); kadmium seperti 1-furoyil-3-benzil-3feniltiourea (Lazo et al. 2006); kuprum seperti 1-furoyil3,3-dietiltiourea (Perez et al. 2010) dan $\mathrm{N}^{1}, \mathrm{~N}^{3}$-bis[[3,5bis(tri-fluorometil)fenil]karbamotioyil]isoftalamida (Kook et al. 2018); plumbum seperti 1,3-bis(N'-benzoyiltioureido) benzena dan 1,3-bis(N'-furoyiltioureido)benzena (Wilson et al. 2010), ferum(III) seperti 1-fenil-3-piridin-2-yiltiourea (Motlagh et al. 2010) dan aluminium seperti glioxal-bistiosemikarbazon (Li et al. 2008). Namun, kajian mendapati bahawa penggunaan sebatian terbitan tiourea sebagai ionofor aluminium masih tidak banyak dilaporkan.

Bagi menilai kesesuaian sebatian baharu sebagai ionofor dalam sensor ion potensiometri, kajian pengkompleksan antara sebatian tersebut dengan ion sasaran lazimnya dijalankan. Kajian tersebut adalah tergolong dalam bidang kimia supramolekul dan kompleks yang dibentuk digelarkan sebatian supramolekul atau kompleks perumah-tetamu (Vandana 2018). Interaksi yang terbentuk merupakan interaksi dwikutub-ion; ion (asid Lewis) berkoordinat dengan bahagian ligan yang berkutub (bes Lewis) melalui pasangan elektron tunggal.
Ikatan koordinat ini mempunyai komponen kovalen yang ketara, kuat dan supramolekul yang dibentuk adalah stabil (Faridbod et al. 2008).

Kajian pengkompleksan dapat dijalankan melalui pelbagai kaedah, seperti spektroskopi NMR (Misra et al. 2009), spektrofotometri (Zhang et al. 2015) dan konduktometri (Suhud et al. 2015). Walaupun kaedah tersebut mempunyai ketepatan pengukuran yang tinggi, kaedah spektrofluorimetri memaparkan kelebihan yang lebih unik iaitu sifat kepekaan yang sangat tinggi (Granadero et al. 2010). Isyarat pendarfluor boleh dipantau melalui spektrum pengujaan serta pemancaran, keamatan dan nisbah keamatan, memberikan maklumat penting terhadap kajian pengkompleksan (Vandana 2018). Selain itu, pergabungan ion logam dengan ligan organik untuk menghasilkan kompleks yang berpendarflour merupakan satu kaedah analisis yang khusus (Al-kindy et al. 2015). Ion aluminium tidak berpendarflour secara semula jadi. Namun, ion ini boleh berkompleks dengan ligan yang bersifat fluorogenik, menghasilkan ion kompleks yang akan meningkatkan atau menurunkan keamatan pendarflour, untuk analisis pengkompleksan.

Dalam kajian ini, satu sebatian bis-tiourea baru 1,1'-[(metilazanediyil)bis(etana-2,1-diyil)]bis[3-(naftalen1-yil)tiourea] (ACH) disintesis dan dicirikan (Rajah 1). Sebatian ini dipilih kerana sensor ion potensiometri yang direka bentuk berasaskan sebatian ACH telah menunjukkan kepekaan dan kepilihan yang tinggi terhadap ion aluminium berbanding dengan kation yang lain seperti $\mathrm{K}^{+}, \mathrm{Ca}^{2+}, \mathrm{Pb}^{2+}$, $\mathrm{Cu}^{2+}, \mathrm{Hg}^{2+}$ dan $\mathrm{Fe}^{3+}$ (Kook 2019). Sebatian ini dijangka mempunyai penderma atom sulfur dan nitrogen untuk berkoordinat dengan ion aluminium. Selain itu, sebatian ini mempunyai lebih banyak penderma atom berbanding sebatian mono-tiourea kerana mengandungi bis-tiourea moieti sebagai kumpulan berfungsi atau digelarkan sebagai podan (Wilson et al. 2010). Kelebihan tersebut dapat meningkatkan kestabilan pengikatannya terhadap ion aluminium. Oleh itu, bagi menilai dan menentusah kesesuaian sebatian ACH sebagai ionofor aluminium, kajian pengkompleksan antara ligan $\mathrm{ACH}$ dengan ion aluminium melalui kaedah spektrofluorimetri dijalankan. Akhirnya, untuk menentukan struktur geomerti ion kompleks yang dibentuk, pengiraan teori fungsi ketumpatan (DFT) dengan menggunakan program Gaussian 09 juga dijalankan.<smiles></smiles>

RAJAH 1. Struktur 1,1'-[(metilazanediyil)bis(etana-2,1-diyil)] bis[3-(naftalen-1-yil)tiourea] (ACH) 


\section{BAHAN \& KAEDAH}

\section{BAHAN KIMIA}

Bahan kimia yang digunakan ialah 1-naftil isotiosianat (Sigma Aldrich), 2,2'-diamino- $N$-metildietilamina (Santa Cruz Biotechnology), diklorometana, DKM (Fisher Chemicals), dimetil sulfoksida, DMSO (Friendemann Schmidt), aluminium klorida (Acros) dan etanol (SYSTERM). Air ternyahion (rintangan spesifik, $18.0 \mathrm{M} \Omega \mathrm{cm}$ ) digunakan dalam uji kaji dan diperoleh daripada alat penyahion air (Barnstead Pure Water).

\section{INSTRUMEN}

${ }^{1} \mathrm{H}$ dan ${ }^{13} \mathrm{C}$ spektroskopi resonan magnetik nukleus, RMN (JEOL JNM-ECP 400), spektroskopi inframerah, IM (Perkin Elmer), spektrometri jisim, SJ (Bruker Daltonics) dan spektroskopi pendarflour (Perkin Elmer) digunakan.

\section{SINTESIS 1,1'-[(metilazandiyil)-bis(etana-2,1-diyil)] bis[3-(naftalen-1-yil)tiourea], $\mathrm{ACH}$}

Tindak balas refluks antara bahan pemula 1-naftil isotiosianat dengan sebatian terbitan amina, 2,2'-diamino$\mathrm{N}$-metildietilamina, dijalankan menggunakan pelarut DKM untuk menghasilkan sebatian 1,1'-[(metilazandiyil)bis(etana-2,1-diyil)]bis[3-(naftalen-1-yil)tiourea]. Sepanjang tindak balas tersebut dijalankan, ujian kromatografi lapisan nipis dilakukan setiap 2 jam untuk pemantauan proses tindak balas. Seterusnya, hasil akhir tersebut ditimbang, direkodkan serta dianalisis untuk mengenal pasti komposisi dan struktur sebatiannya dengan menggunakan alat analisis seperti spektroskopi IM, ${ }^{1} \mathrm{H}$ dan ${ }^{13} \mathrm{C}$ RMN dan SJ. Hasil pepejal sebatian ini juga turut dilakukan proses penghabluran semula untuk mendapatkan hasil hablur yang tulen dengan melarutkannya dengan pelarut DMSO.

Mp: 87.1 - 90. $3^{\circ} \mathrm{C}$. IM (kepingan $\left.\mathrm{KBr}\right) \mathrm{v}\left(\mathrm{cm}^{-1}\right)$ : 3214 , 3050, 2946, 1526, 1394, dan 1270. ${ }^{1} \mathrm{H}$ NMR (DMSO-d ${ }_{6}$, $400 \mathrm{MHz}) \delta$ (ppm): 9.72 (s, 1H, NH), 7.95 (t, 1H, J=4.0 Hz, $\mathrm{NH}), 7.85$ (d, 2H, J=7.2 Hz, Ar-H), 7.55-7.40 (m, 5H, Ar$\mathrm{H}), 3.47\left(\mathrm{~s}, 2 \mathrm{H}, \mathrm{CH}_{2}\right), 2.50\left(\mathrm{~s}, 2 \mathrm{H}, \mathrm{CH}_{2}\right), 2.15\left(\mathrm{~s}, 3 \mathrm{H}, \mathrm{CH}_{3}\right)$. ${ }^{13} \mathrm{C} \mathrm{RMN}\left(\mathrm{DMSO}-\mathrm{d}_{6}, 100 \mathrm{MHz}\right) \delta(\mathrm{ppm}): 182.0(\mathrm{C}=\mathrm{S})$, 134.7 (Ar-C), 134.4 (Ar-C), 130.2 (Ar-C), 128.5 (Ar-CH), 127.2 (Ar-CH), 126.6 (2 x Ar-CH), 126.2 (ArCH), 125.5 (Ar-CH), dan 123.3 (Ar-CH), $55.7\left(\mathrm{CH}_{2}\right), 42.2\left(\mathrm{CH}_{3}\right)$. $\mathrm{SJ}$ (ESI) m/z: kiraan berat molekul bagi C27H29N5S2 (487.6827), perolehan data $[\mathrm{M}+\mathrm{H}]+(488.1826)$.

KESAN KOMPOSISI PELARUT $\mathrm{H}_{2} \mathrm{O}-\mathrm{ETOH}$ TERHADAP PANJANG GELOMBANG PENGUJAAN DAN PEMANCARAN MAKSIMUM BAGI LIGAN ACH

Lima jenis larutan $\mathrm{H}_{2} \mathrm{O}-\mathrm{EtOH}$ dengan komposisi 99/1, $75 / 25,50 / 50,25 / 75$ dan $0 / 100$ yang mempunyai $10^{-5} \mathrm{M}$ $\mathrm{ACH}$ disediakan. Spektrum pengujaan dan pemancaran bagi ligan $\mathrm{ACH}$ dibaca dan direkodkan. Keamatan pendarfluor diukur dalam sel kuartz $1 \mathrm{~cm}$ dan slit pengujaan dan pemancaran ditetapkan pada $5.0 \mathrm{~nm}$.
KESAN KOMPOSISI PELARUT $\mathrm{H}_{2} \mathrm{O}$-ETOH TERHADAP PENGKOMPLEKSAN ACH-AL ${ }^{3+}$

Bagi kajian pengkompleksan antara ligan $\mathrm{ACH}$ dengan ion aluminium, kajian penitratan melalui kaedah nisbah mol dengan merujuk kepada Fakhar et al. (2017) dan sedikit pengubahsuaian dijalankan. $10^{-3} \mathrm{M}$ larutan stok $\mathrm{ACH}$ dalam pelarut EtOH dan $10^{-3} \mathrm{M}$ larutan stok ion aluminium dalam komposisi pelarut $\mathrm{H}_{2} \mathrm{O}-\mathrm{EtOH}$ tertentu disediakan. Sebanyak $100 \mu \mathrm{L}$ daripada larutan stok $\mathrm{ACH}$ dipipetkan ke dalam $10 \mathrm{~mL}$ kelalang isi padu. Kemudian, isi padu daripada larutan stok ion aluminium diambil antara 0 hingga $60 \mu \mathrm{L}$ dan dimasukkan juga ke dalam kelalang isi padu yang sama. Akhirnya, pelarut $\mathrm{H}_{2} \mathrm{O}$ dan EtOH ditambahkan sehingga mencapai senggatan untuk mendapatkan komposisi pelarut $\mathrm{H}_{2} \mathrm{O}-\mathrm{EtOH}$ yang dikehendaki.

Setiap larutan ion kompleks ACH- $\mathrm{Al}^{3+}$ yang disediakan diujakan pada panjang gelombang pengujaan maksimum masing-masing dan spektrum pemancaran direkodkan. Keamatan pendarfluor bagi setiap kepekatan larutan ion kompleks ACH-Al ${ }^{3+}$ diukur dan dicatatkan. Graf perubahan keamatan pendarflour F-F melawan $\left[\mathrm{Al}^{3+}\right] /[\mathrm{ACH}]$ diplotkan dengan $\mathrm{F}$ merupakan keamatan pendarflour bagi ion kompleks $\mathrm{ACH}-\mathrm{Al}^{3+}$ dan $\mathrm{F}_{\mathrm{o}}$ merupakan keamatan ligan ACH sahaja. Daripada graf tersebut, kecenderungan ion kompleks dibentuk dalam komposisi pelarut tertentu dapat diketahui. Stoikoimetri ion kompleks pula ditentukan melalui titik pertemuan antara dua garis linear.

\section{PENENTUAN PEMALAR PENCERAIAN, $\mathrm{K}_{\mathrm{D}}$ DAN PEMALAR PENYEKUTUAN, $\mathrm{K}_{\mathrm{A}}$}

Dalam penentuan pemalar penceraian, $\mathrm{K}_{\mathrm{d}}$, bagi ion kompeks $\left[\mathrm{Al}(\mathrm{ACH})_{3}\right]^{3+}$, satu graf garis-fit diplotkan melalui persamaan regresi bukan linear dengan menggunakan program Sigma 12.0 (Systat Software Inc.). Persamaan regresi bukan linear yang digunakan adalah seperti berikut:

$$
y=\frac{B_{\max } x}{K_{d}+x}
$$

dengan $\mathrm{B}_{\max }$ merupakan kompleks $[\mathrm{H}-\mathrm{G}]$ iaitu $\left[\mathrm{Al}(\mathrm{ACH})_{3}\right]^{3+}$, $\mathrm{x}$ merupakan $[\mathrm{Al}]^{3+}$ dan y merupakan perbezaan keamatan pendarflour F-F (Fakhar et al. 2017; Stewart 2002). Kaedah ini juga digunakan untuk penentuan nilai pekali korelasi hasil Pearson, R. Bagi nilai pemalar penyekutuan, $K_{a}$, nilai ini ditentukan melalui pengiraan $1 / K_{d}$ (Fakhar et al. 2017).

\section{PENGIRAAN TEORI FUNGSI KETUMPATAN (DFT) BAG PENENTUAN STRUKTUR ION KOMPLEKS}

Geometri pengoptimuman dan pengiraan jumlah tenaga ditentukan dalam keadaan fasa gas dengan menggunakan pengiraan teori fungsi ketumpatan (DFT). Geometri bagi ligan $\mathrm{ACH}$ dioptimumkan dengan kaedah RB3LYP, set asas 6-31G(d,p) manakala geometri aluminium serta kompleks $[\mathrm{ACH}-\mathrm{Al}]^{3+}$ dioptimumkan dengan kaedah UB3LYP, set asas GEN. Program Gaussion 09W digunakan 
untuk semua pengoptimuman geometri dan pengiraan (Dennington et al. 2016; Ullah et al. 2013). Akhirnya, tenaga pengikatan, $\mathrm{E}_{\text {(pengikatan) }}$ bagi ion kompleks $[\mathrm{ACH}: \mathrm{Al}]^{3+}$ dengan stokoimetri 1:1 dihitung dengan merujuk kepada persamaan berikut:

$$
\begin{aligned}
& \mathrm{E}_{\text {(interaksi tanpa diperbetulkan) }}=\left[\mathrm{E}_{\text {(ion aluminium) }}+\mathrm{E}_{\text {(ligan ACH) }}\right] \\
& \left.\mathrm{E}_{(\text {kompleks tanpa diperbetulkan) }}=\mathrm{E}_{\text {(ion kompleks ACH-Al }}{ }^{3+}\right)^{-} \\
& \mathrm{E}_{\text {(interaksi tanpa diperbetulkan) }}
\end{aligned}
$$

(a)
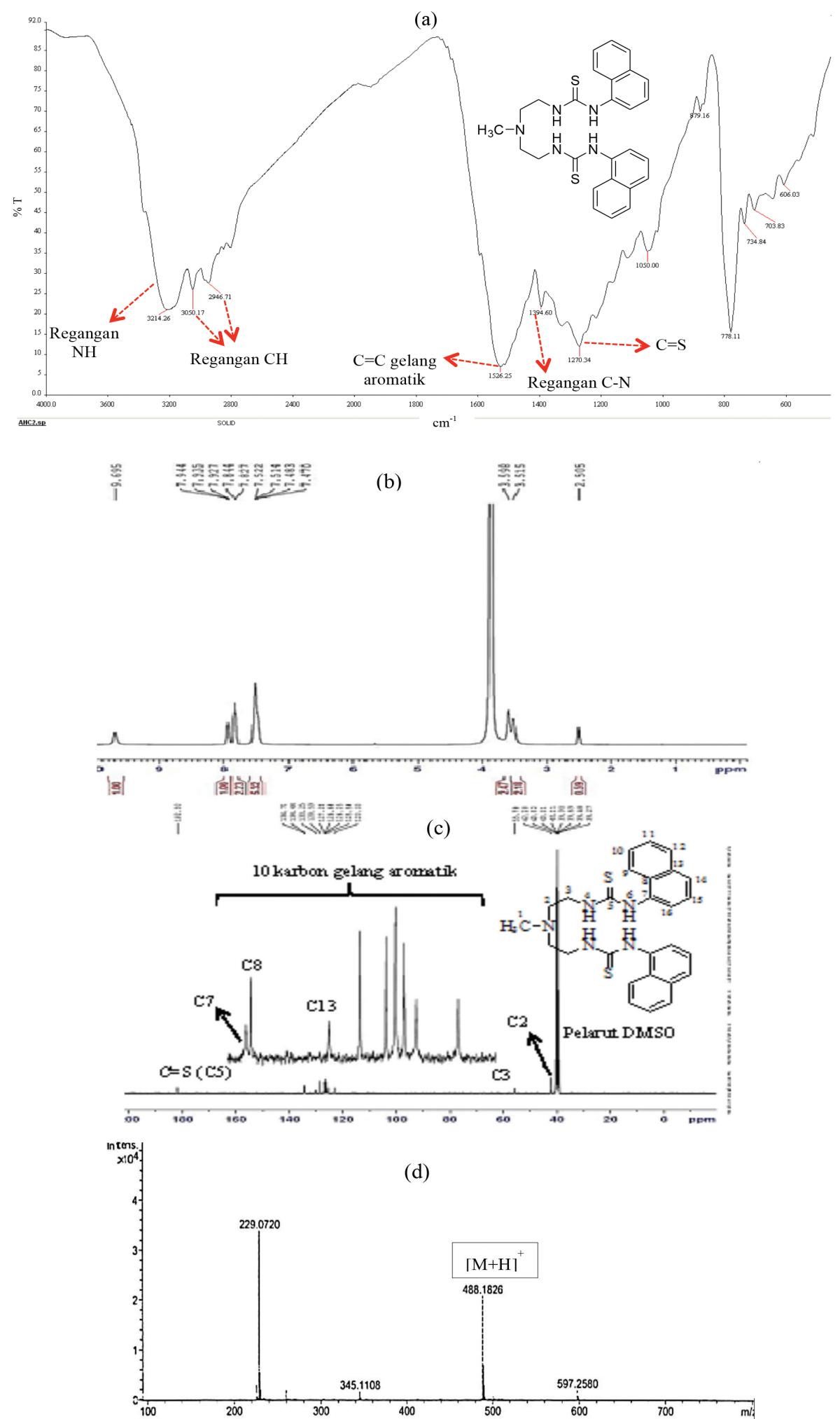

RAJAH 2. Spektrum (a) IM, (b) 1H RMN, (c) 13C RMN dan (d) SJ bagi sebatian 1,1'-[(metilazandiyil)bis(etana-2,1-diyil)]bis[3-(naftalen-1-yil)tiourea], $\mathrm{ACH}$ 
$\mathrm{E}_{\text {(pengikatan) }}=\mathrm{E}_{(\text {kompleks tanpa diperbetulkan) }}+\mathrm{E}_{(\text {set asas ralat superposisi) }}$

\section{KEPUTUSAN DAN PERBINCANGAN}

\section{PENCIRIAN SEBATIAN ACH MELALUI SPEKTROSKOPI IM, RMN-1H, RMN-13C DAN JS}

Peratusan hasil yang diperoleh bagi sebatian ACH adalah $76 \%$. Bagi pencirian sebatian $\mathrm{ACH}$, spektrum IM (Rajah 2(a)) menunjukkan puncak-puncak serapan bagi kumpulan berfungsi yang diperoleh bagi $\mathrm{ACH}$, iaitu $\mathrm{NH}, \mathrm{C}-\mathrm{H}, \mathrm{C}-\mathrm{N}$, $\mathrm{C}=\mathrm{C}$ dan $\mathrm{C}=\mathrm{S}$ (kumpulan berfungsi utama). Berdasarkan spektrum tersebut, semua puncak bagi kumpulan berfungsi yang hadir dalam sebatian ini berjaya dikenal pasti dan membuktikan sebatian tersebut mungkin berjaya dihasilkan. Selain itu, spektrum RMN 1H dan 13C (Rajah 2(b) dan 2(c)) juga jelas membuktikan sebatian ACH berjaya dihasilkan dengan bilangan proton sebanyak 16 mengikut nilai kamiran pada spektrum tersebut. Spektrum SJ (Rajah 2(d)) juga berjaya diperoleh mengikut berat molekul sebatian ACH jangkaan dan satu ion hidrogen.

\section{KESAN KOMPOSISI PELARUT $\mathrm{H}_{2} \mathrm{O}$-ETOH TERHADAP PANJANG GELOMBANG PENGUJAAN DAN PEMANCARAN MAKSIMUM BAGI LIGAN ACH}

Dalam kajian pengkompleksan, pelarut menyediakan media yang sesuai untuk tindak balas tersebut. Pelarut yang digunakan dalam kajian ini adalah etanol (EtOH) dan air $\left(\mathrm{H}_{2} \mathrm{O}\right)$ (Payehghadr \& Hashemi 2017). Pelarut $\mathrm{H}_{2} \mathrm{O}-\mathrm{EtOH}$ dipilih kerana ligan $\mathrm{ACH}$ dan ion aluminium dapat melarut secara penuh dalam campuran pelarut tersebut. Pelarutan penuh dapat mengelakkan kesilapan akibat penyerakan cahaya.

Setiap komposisi pelarut $\mathrm{H}_{2} \mathrm{O}-\mathrm{EtOH}$ mempunyai kekutuban yang berbeza. Komposisi $99 \% \mathrm{H}_{2} \mathrm{O}-1 \%$ EtOH mempunyai kekutuban pelarut yang paling tinggi manakala komposisi pelarut $0 \% \mathrm{H}_{2} \mathrm{O}-100 \%$ EtOH adalah paling kurang berkutub. $100 \% \mathrm{H}_{2} \mathrm{O}-0 \%$ EtOH tidak dapat dijalankan kerana ligan $\mathrm{ACH}$ tidak melarut dalam $100 \% \mathrm{H}_{2} \mathrm{O}$. Kekutuban persekitaran ligan akan mempengaruhi panjang gelombang pengujaan dan pemancaran maksimumnya (Lakowicz 1983). Justeru, kesan komposisi pelarut $\mathrm{H}_{2} \mathrm{O}-\mathrm{EtOH}$ terhadap dua jenis panjang gelombang maksimum bagi ligan $\mathrm{ACH}$ dikajikan sebelum kajian pengkompleksan dijalankan.

Berdasarkan kepada Rajah 3 dan Jadual 1, apabila kekutuban pelarut $\mathrm{H}_{2} \mathrm{O}-\mathrm{EtOH}$ semakin tinggi, didapati bahawa panjang gelombang pengujaan maksimum menghadapi peralihan biru. Peralihan biru atau hipsokromik dengan peningkatan kekutuban pelarut juga dipanggil sebagai 'solvatokromism negatif' (Reichardt 1994). Solvatokromism adalah disebabkan oleh pembezaan pensolvatan pada keadaan asas dan keadaan teruja bagi molekul tersebut. Jenis komposisi pelarut akan mempengaruhi sifat pengujaan molekul melalui kecenderungan pelarut untuk menstabilkan keadaan asas atau keadaan teruja. Bagi kekutuban pelarut yang lebih tinggi, keadaan asas adalah lebih berkutub berbanding dengan keadaan pengujaan. Situasi ini menyebabkan keadaan asas lebih cenderung distabilkan oleh pensolvatan berbanding dengan keadaan teruja. Akibatnya, jurang tenaga antara keadaan asas dan keadaan teruja ditingkatkan. Justeru, solvakromism negatif telah diperoleh (Reichardt 1994).
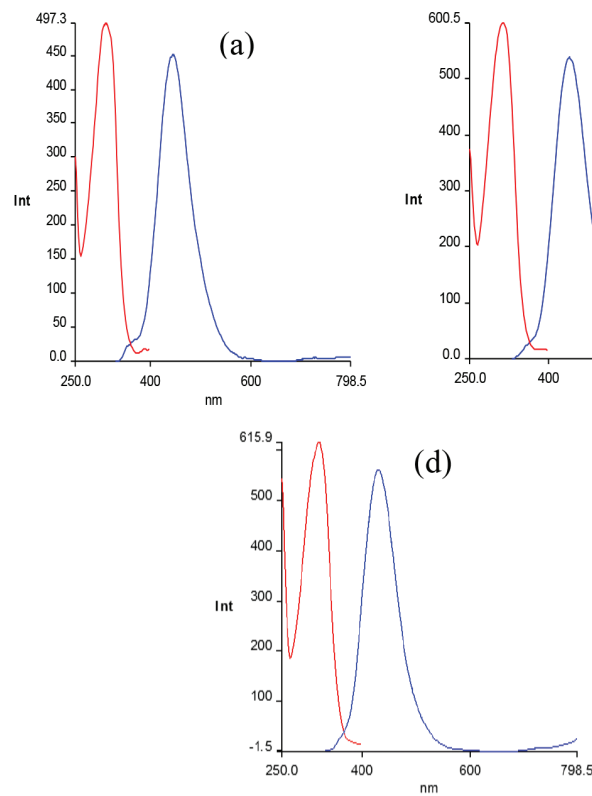
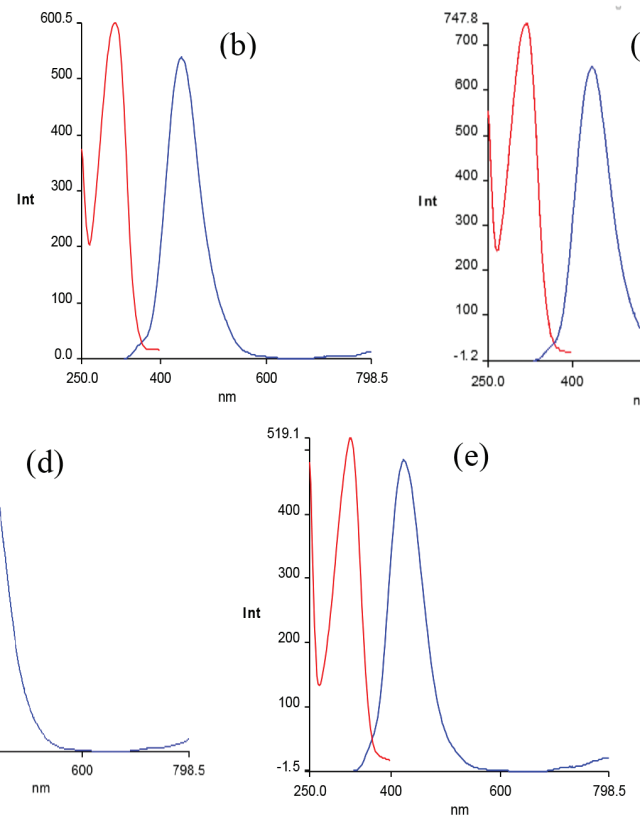

(c)

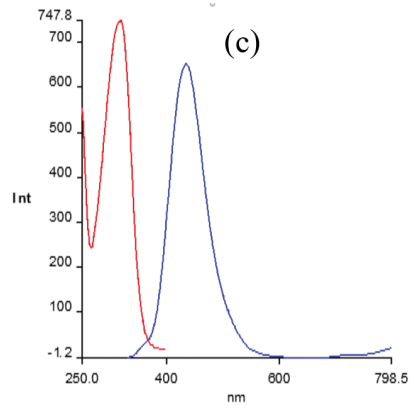

(e)

RAJAH 3. Spektrum pengujaan (garisan merah) dan pemancaran (garisan biru) bagi ligan $\mathrm{ACH}\left(1 \times 10^{-5} \mathrm{M}\right)$ dalam komposisi pelarut $\mathrm{H}_{2} \mathrm{O}-\mathrm{EtOH}$ yang berbeza (a) $99 \% \mathrm{H}_{2} \mathrm{O}-1 \% \mathrm{EtOH}$, (b) $75 \% \mathrm{H}_{2} \mathrm{O}-25 \% \mathrm{EtOH}$, (c) $50 \% \mathrm{H}_{2} \mathrm{O}$ $50 \%$ EtOH, (d) $25 \% \mathrm{H}_{2} \mathrm{O}-75 \% \mathrm{EtOH}$ dan (e) $0 \% \mathrm{H}_{2} \mathrm{O}-100 \% \mathrm{EtOH}$ 
JADUAL 1. Komposisi pelarut $\mathrm{H}_{2} \mathrm{O}-\mathrm{EtOH}$ yang berbeza terhadap panjang gelombang pengujaan dan pemancaran maksimum bagi ligan $\mathrm{ACH}\left(1 \times 10^{-5} \mathrm{M}\right)$

\begin{tabular}{cccc}
\hline Jenis Pelarut & Komposisi pelarut & $\begin{array}{c}\text { Panjang gelombang pengujaan } \\
\text { maksimum (nm) }\end{array}$ & $\begin{array}{c}\text { Panjang gelombang pemancaran } \\
\text { maksimum }(\mathrm{nm})\end{array}$ \\
\hline $\mathrm{a}$ & $99 \% \mathrm{H}_{2} \mathrm{O}-1 \% \mathrm{EtOH}$ & 310.00 & 443.00 \\
$\mathrm{~b}$ & $75 \% \mathrm{H}_{2} \mathrm{O}-25 \% \mathrm{EtOH}$ & 314.00 & 438.00 \\
$\mathrm{c}$ & $50 \% \mathrm{H}_{2} \mathrm{O}-50 \% \mathrm{EtOH}$ & 317.00 & 432.00 \\
$\mathrm{~d}$ & $25 \% \mathrm{H}_{2} \mathrm{O}-75 \% \mathrm{EtOH}$ & 319.00 & 429.00 \\
$\mathrm{e}$ & $0 \% \mathrm{H}_{2} \mathrm{O}-100 \% \mathrm{EtOH}$ & 324.00 & 423.00 \\
\hline
\end{tabular}

Bagi panjang gelombang pemancaran maksimum, peralihan merah diperoleh bagi pelarut $\mathrm{H}_{2} \mathrm{O}$-EtOH yang semakin berkutub (Rajah 3; Jadual 1). Keadaan ini boleh dijelaskan dengan fenomena pemancaran suatu fluorofor. Apabila fluorofor diujakan ke aras getaran yang lebih tinggi pada keadaan singlet teruja pertama,S1, tenaga getaran yang berlebihan akan hilang ke molekul pelarut persekitaran sementara fluorofor mengendur secara lambat ke aras tenaga getaran terendah. Proses ini berlaku pada piko saat. Molekul pelarut pula akan membantu dalam penstabilan. Molekul pelarut akan menurunkan aras tenaga keadaan teruja melalui orentasi semula pada sekitar fluorofor yang teruja. Keadaan ini juga digelarkan sebagai pengenduran pelarut. Proses ini adalah lebih lambat dan memerlukan masa 10-100 piko saat. Akibatnya, proses ini membawa kepada pengurangan tenaga pemisahan antara keadaan asas dan keadaan teruja. Justeru, panjang gelombang pemancaran yang lebih panjang diperoleh. Apabila kekutuban pelarut semakin tinggi, pengurangan pada aras tenaga keadaan teruja adalah lebih besar. Oleh itu, peralihan merah diperoleh apabila kekutuban pelarut ditingkatkan (Reinhoudt 1992).

\section{KESAN KOMPOSISI PELARUT $\mathrm{H}_{2} \mathrm{O}-\mathrm{ETOH}$ TERHADAP PENGKOMPLEKSAN ACH-AL ${ }^{3+}$}

Kestabilan ion kompleks sangat bergantung kepada kebolehan pelarut dalam melarut kation dan ligan. Bagi penghasilan ion kompleks, ligan harus menggantikan pelarut secepat mungkin pada petala pensolvatan pertama kation, atau kation harus menggantikan molekul pelarut dengan ligan. Perubahan pada kekutuban pelarut akan mempengaruhi sifat pengikatan ligan (Kolusheva et al. 2012). Oleh itu, kesan komposisi pelarut $\mathrm{H}_{2} \mathrm{O}-\mathrm{EtOH}$ yang berbeza terhadap pembentukan ion kompleks $\mathrm{ACH}-\mathrm{Al}^{3+}$ dijalankan.

Lima jenis spektrum pemancaran diperoleh setelah diujakan pada panjang gelombang pengujaan maksimum masing-masing (Lampiran 1). Tindak balas pengkompleksan antara ligan $\mathrm{ACH}$ dengan ion aluminium dapat dilihat pada Rajah 4. Bagi pelarut $99 \% \mathrm{H}_{2} \mathrm{O}-1 \% \mathrm{EtOH}$ dan $75 \% \mathrm{H}_{2} \mathrm{O}-25 \% \mathrm{EtOH}$, penambahan kepekatan ion aluminium dari 0 hingga $1.5 \times 10^{-6} \mathrm{M}(0.0 / 1.0$ hingga $\left.0.15 / 1.0\left[\mathrm{Al}^{3+}\right] /[\mathrm{ACH}]\right)$ telah menunjukkan peningkatan pada keamatan pendarflour. Selepas kepekatan tersebut, tiada perubahan yang ketara dan pelindapan pada keamatan pendarflour ditunjukkan. Bagi pelarut $50 \% \mathrm{H}_{2} \mathrm{O}-50 \% \mathrm{EtOH}$, penambahan kepekatan ion aluminium daripada 0 hingga $2.0 \times 10^{-6} \mathrm{M}\left(0.0 / 1.0\right.$ hingga $\left.0.2 / 1.0\left[\mathrm{Al}^{3+}\right] /[\mathrm{ACH}]\right)$ telah menunjukkan peningkatan pada keamatan pendarflour. Selepas kepekatan tersebut, pelindapan pada keamatan pendarflour ditunjukkan.

Peningkatan keamatan pendarflour sehingga nisbah $0.15 / 1.0$ atau 0.2/1.0 [Al $\left.{ }^{3+}\right] /[\mathrm{ACH}]$ menunjukkan stoikoimetri 6 atau 5 ligan $\mathrm{ACH}$ berkoordinat dengan 1 ion aluminium. Namun, ligan ACH adalah bermolekul besar. Masalah halangan sterik akan dihadapi untuk pembentukan jenis ion kompleks tersebut. Justeru, pembentukan ion kompleks dikatakan tidak berjaya dalam tiga jenis komposisi pelarut tersebut.

Nisbah $\mathrm{H}_{2} \mathrm{O}$ yang tinggi merupakan sebab kegagalan dalam penghasilan ion kompleks $\mathrm{ACH}-\mathrm{Al}^{3+}$. Garam aluminium klorida yang digunakan dalam kajian ini setelah dilarutkan dalam $\mathrm{H}_{2} \mathrm{O}$, ion kompleks $\left[\mathrm{Al}\left(\mathrm{H}_{2} \mathrm{O}\right)_{6}\right]^{3+}$ terbentuk dengan ion aluminium dikelilingi oleh enam ligan molekul air dan mempunyai geometri oktahedral. Oleh itu, semakin tinggi nisbah $\mathrm{H}_{2} \mathrm{O}$ dalam pelarut, semakin banyak ion aluminium disolvat oleh molekul $\mathrm{H}_{2} \mathrm{O}$. Akibatnya, terdapat persaingan yang kuat antara $\mathrm{H}_{2} \mathrm{O}$ dengan $\mathrm{ACH}$ untuk membentuk ion kompleks $\mathrm{ACH}-\mathrm{Al}^{3+}$ (Suhud et al. 2015).

Pelindapan pada keamatan pendarflour pula disebabkan ikatan hidrogen telah berlaku antara $\mathrm{H}_{2} \mathrm{O}$ dengan ligan $\mathrm{ACH}$. Molekul $\mathrm{H}_{2} \mathrm{O}$, dengan struktur $\mathrm{H}-\mathrm{O}-\mathrm{H}$, merupakan penderma dan penerima ikatan hidrogen yang bagus. Ligan $\mathrm{ACH}$ pula merupakan terbitan bis-tiourea yang mempunyai dua kumpulan berfungsi $-\mathrm{S}=\mathrm{C}-\mathrm{NH}$. Dengan kehadiran $\mathrm{H}_{2} \mathrm{O}$ yang tinggi dalam tiga komposisi pelarut tersebut, ikatan hidrogen dibentuk antara atom hidrogen daripada molekul H-O-H dengan atom nitrogen daripada $\mathrm{HN}-\mathrm{C}=\mathrm{S}-$. Akibatnya, peralihan cas berlaku dan ligan $\mathrm{ACH}$ yang diprotonkan menghadapi pengurangan elektron. Justeru, pelindapan pada keamatan pendarflour ditunjukkan (Doroshenko \& Pivovarenko 2003; Herbich et al. 1994).

Bagi komposisi pelarut $25 \% \mathrm{H}_{2} \mathrm{O}-75 \% \mathrm{EtOH}$, penambahan kepekatan ion aluminium daripada 0 hingga $3.5 \times 10^{-6} \mathrm{M}\left(0\right.$ hingga $\left.0.35 / 1.0\left[\mathrm{Al}^{3+}\right] /[\mathrm{ACH}]\right)$ menunjukkan peningkatan pada keamatan pendarflour. Selepas kepekatan tersebut, keamatan pendarflour menjadi tetap. Keadaan ini menunjukkan terbentuknya ion kompleks yang stabil. Stoikiometri bagi ion kompleks yang terbentuk antara ligan $\mathrm{ACH}$ dan ion $\mathrm{Al}^{3+}$ ialah 3:1. Peningkatan pada keamatan pendarfluor adalah disebabkan peningkatan dalam 
ketegaran ion kompleks $\mathrm{ACH}-\mathrm{Al}^{3+}$ apabila dibandingkan dengan ligan ACH sahaja (Al-kindy et al. 2015).

Bagi komposisi pelarut $0 \% \mathrm{H}_{2} \mathrm{O}-100 \%$ EtOH, peningkatan pada keamatan pendarflour ditunjukkan bagi penambahan kepekatan ion aluminium daripada 0 hingga $1.0 \times 10^{-6} \mathrm{M}\left(0\right.$ hingga $\left.0.1 / 1.0\left[\mathrm{Al}^{3+}\right] /[\mathrm{ACH}]\right)$. Selepas kepekatan tersebut, tiada perubahan yang ketara dan pelindapan pada keamatan pendarflour ditunjukkan pada akhirnya. Keadaan ini menunjukkan pembentukan ion kompleks $\mathrm{ACH}-\mathrm{Al}^{3+}$ adalah tidak berjaya. Kegagalan berlakunya pengkompleksan adalah disebabkan interaksi EtOH dengan $\mathrm{AlCl}_{3}$ dalam membentuk sebatian $\mathrm{AlCl}(\mathrm{OEt})_{2}, \mathrm{AlCl}_{2}(\mathrm{OEt}) \cdot 2 \mathrm{AlCl}_{3} \cdot 10 \mathrm{EtOH}, \mathrm{AlCl}_{2}(\mathrm{OEt})$ atau $\mathrm{AlCl}_{2}(\mathrm{OEt}) \cdot 5 \mathrm{EtOH}$ (Starnes et al. 1997). Dalam 100\%EtOH, ion aluminium, $\mathrm{Al}^{3+}$ yang bebas untuk berkompleks dengan ligan ACH tidak dapat dihasilkan. Justeru, didapati bahawa sedikit $\mathrm{H}_{2} \mathrm{O}$ adalah diperlukan untuk menghasilkan ion $\mathrm{Al}^{3+}$ dari $\mathrm{AlCl}_{3}$ bagi pembentukan ion kompleks.

Daripada hasilan kajian, didapati hanya komposisi pelarut $25 \% \mathrm{H}_{2} \mathrm{O}-75 \%$ EtOH menunjukkan pembentukan ion kompleks $\left[\mathrm{Al}(\mathrm{ACH})_{3}\right]^{3+}$. Persamaan pembentukan ion kompleks adalah ditunjukkan seperti berikut:

$$
3 \mathrm{ACH}+\mathrm{Al}^{3+} \rightleftarrows\left[\mathrm{Al}(\mathrm{ACH})_{3}\right]^{3+}
$$

\section{PENENTUAN KESTABILAN ION KOMPLEKS $\left[\mathrm{AL}(\mathrm{ACH})_{3}\right]^{3+}$ SEBAGAI IONOFOR ALUMINIUM}

Kestabilan ion kompleks $\left[\mathrm{Al}(\mathrm{ACH})_{3}\right]^{3+}$ yang dibentuk dapat ditentukan melalui nilai pemalar penceraian, $\mathrm{K}_{\mathrm{d}}$ dan pemalar penyekutuan $\left(\mathrm{K}_{\mathrm{a}}\right)$. Nilai $\mathrm{K}_{\mathrm{a}}$ yang tinggi dan $\mathrm{K}_{\mathrm{d}}$ yang rendah menunjukkan bahawa sebatian ion kompleks yang dihasilkan adalah stabil.

Melalui keputusan yang diperoleh daripada program SigmaPlot, nilai $\mathrm{K}_{\mathrm{d}}$, bagi ion kompleks $\left[\mathrm{Al}(\mathrm{ACH})_{3}\right]^{3+}$ ialah $(8.01 \pm 0.13) \times 10^{-6} \mathrm{M}$ manakala nilai $\mathrm{K}_{\mathrm{a}}$ yang dikira daripada $1 / \mathrm{K}_{\mathrm{d}}$ ialah $(1.25 \pm 0.02) \times 10^{5} \mathrm{M}^{-1}$. Selain itu, nilai pekali kolerasi hasil Pearson, $\mathrm{R}$ yang diperoleh daripada graf baris-fit ialah 0.954 . Nilai yang diperoleh memaparkan bahawa korelasi yang positif dan baik telah ditunjukkan bagi perubahan F-F terhadap $[\mathrm{Al}]^{3+}$ (Fakhar \& Hasbullah 2018). Justeru, ion kompleks $\left[\mathrm{Al}(\mathrm{ACH})_{3}\right]^{3+}$ yang dihasilkan adalah stabil.

Tambahan pula, nilai $\mathrm{pK}_{\mathrm{a}}$ yang merupakan nilai logaritma $\mathrm{K}_{\mathrm{a}}$, memberikan maklumat penting bagi kesesuaian ligan digunakan sebagai ionofor (Khairi 2016). Nilai $\mathrm{pK}_{\mathrm{a}}$ yang diperoleh dalam kajian ini ialah $5.10 \pm 0.01$. Nilai ini adalah setara dengan keputusan yang dilaporkan oleh Yan et al. (2014) kerana bagi sensor ion aluminium potensiometri yang berjaya dibina, ionofor yang digunakan, iaitu [(E)-N-[4-(dimetililamina)benzilidena]1H-benzo[d]midazob-2-hidrazida] (L), menunjukkan nilai $\mathrm{pK}_{\mathrm{a}} 5.25$ bagi ion kompleks ${\mathrm{L}-\mathrm{Al}^{3+}}^{3}$ yang dibentuk. Justeru, nilai $\mathrm{pK}_{\mathrm{a}}$ yang diperoleh dalam kajian ini telah memaparkan bahawa ligan ACH adalah sesuai sebagai ionofor aluminium dalam sensor ion potensiometri.

\section{PENENTUAN STRUKTUR ION KOMPLEKS $\left[\mathrm{AL}(\mathrm{ACH})_{3}\right]^{3+}$ DENGAN MENGGUNAKAN PENGIRAAN DFT}

Bagi mengetahui geometri dan jenis mod pengikatan bagi ion kompleks $\left[\mathrm{Al}(\mathrm{ACH})_{3}\right]^{3+}$, pengoptimuman bagi
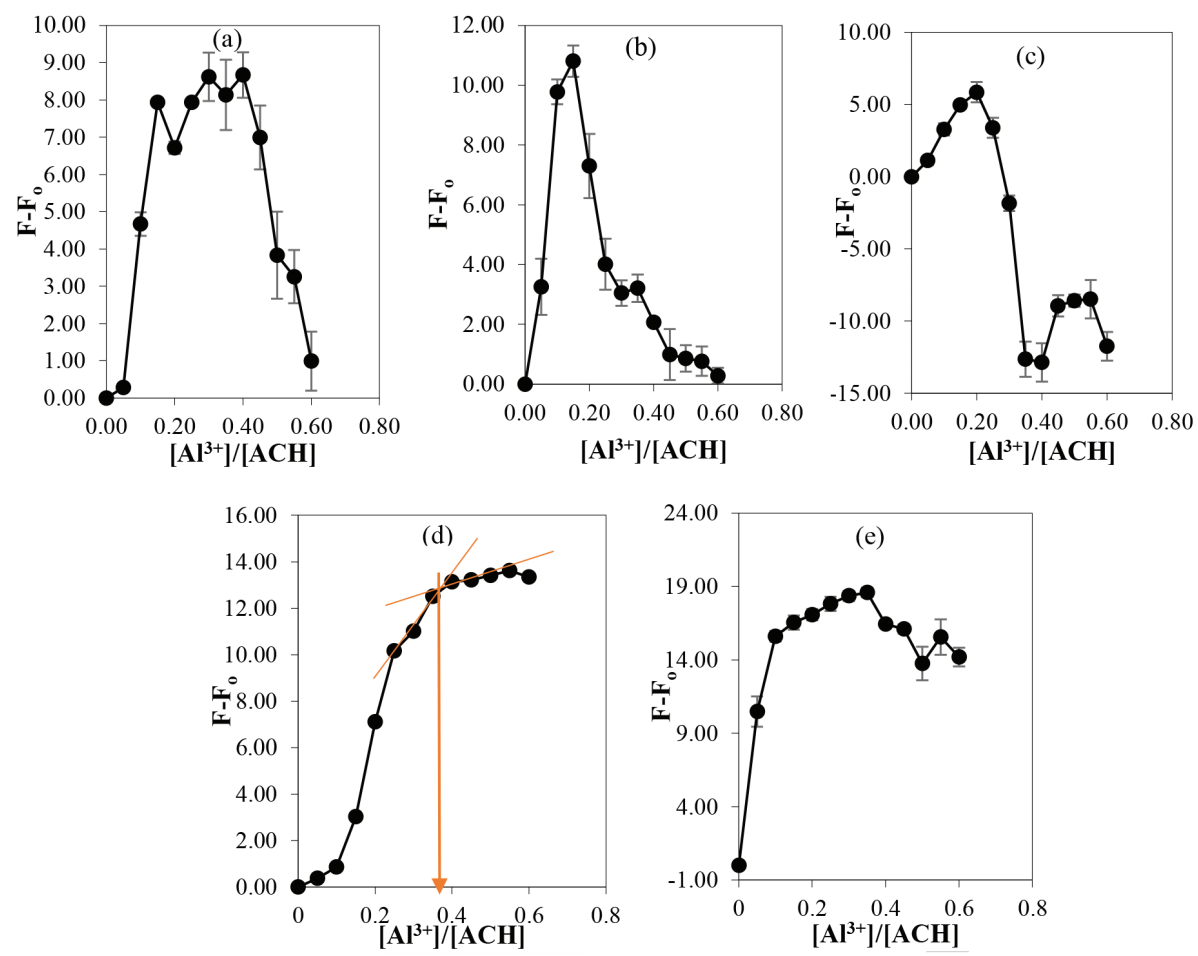

RAJAH 4. Perubahan keamatan pendarflour bagi ion kompleks ACH-Al ${ }^{3+}$ dalam komposisi pelarut $\mathrm{H}_{2} \mathrm{O}-\mathrm{EtOH}$ yang berbeza (a) $99 \% \mathrm{H}_{2} \mathrm{O}-1 \% \mathrm{EtOH}$, (b) $75 \% \mathrm{H}_{2} \mathrm{O}-25 \% \mathrm{EtOH}$, (c) $50 \% \mathrm{H}_{2} \mathrm{O}-50 \% \mathrm{EtOH}$,

(d) $25 \% \mathrm{H}_{2} \mathrm{O}-75 \% \mathrm{EtOH}$ dan (e) $0 \% \mathrm{H}_{2} \mathrm{O}-100 \% \mathrm{EtOH}$ 
geometri ion kompleks $[\mathrm{Al}(\mathrm{ACH})]^{3+}$ dalam stoikoimetri 1:1 dijalankan melalui pengiraan DFT. Merujuk kepada Rajah 5, selepas pengoptimuman pada geometri, dua panjang ikatan S-Al, iaitu $2.39 \AA$ telah diperoleh dan nilai ini adalah menghampiri nilai teori. Keadaan ini menunjukkan bahawa atom sulfur daripada dua kumpulan berfungsi bis-tiourea ACH masing-masing terlibat dalam pengkoordinatan dengan ion aluminium (Carmalt et al. 2003). Ligan ACH merupakan ligan bidendat kepada ion aluminium. Bagi struktur 3 dimensi yang telah diperoleh, geometri separa rongga ditunjukkan pada ligan $\mathrm{ACH}$ untuk berkoordinat dengan ion aluminium. Atom nitrogen juga didapati tidak terlibat dalam pengkompleksan.

Melalui kepada pengiraan DFT, tenaga bagi ion kompleks $[\mathrm{Al}(\mathrm{ACH})]^{3+}$ ialah $-5.562 \times 10^{6} \mathrm{~kJ} / \mathrm{mol}$ adalah lebih rendah daripada ligan ACH sahaja, -5.556 $\times 10^{6} \mathrm{~kJ} / \mathrm{mol}$ (Jadual 2). Tenaga yang lebih rendah adalah disebabkan kesan pempolaran telah berlaku dengan kehadiran ion aluminium pada ligan ACH dan menunjukkan ion kompleks telah berjaya dihasilkan (Bakó \& Mayer 2016). Selain itu, tenaga pengikatan bagi ion kompleks $[\mathrm{Al}(\mathrm{ACH})]^{3+}$ ialah $-5.560 \times 10^{6} \mathrm{~kJ} / \mathrm{mol}$. Nilai negatif yang rendah pula memaparkan bahawa ion kompleks $[\mathrm{Al}(\mathrm{ACH})]^{3+}$ yang terbentuk adalah kuat dan stabil (Kaur et al. 2017).

Oleh itu, bagi geometri ion kompleks $\left[\mathrm{Al}(\mathrm{ACH})_{3}\right]^{3+}$ yang mempunyai stokoimetri 3 ligan $\mathrm{ACH}$ kepada 1 $\mathrm{Al}^{3+}$ ion, dengan merujuk kepada struktur $[\mathrm{Al}(\mathrm{ACH})]^{3+}$, adalah dicadangkan seperti pada Rajah 6. Dalam struktur ion kompleks $\left[\mathrm{Al}(\mathrm{ACH})_{3}\right]^{3+}$, setiap ligan $\mathrm{ACH}$ akan menyumbang dua ikatan koordinat kepada ion aluminium. Justeru, 1 ion $\mathrm{Al}^{3+}$ akan dikelilingi dengan 3 ligan $\mathrm{ACH}$ melalui enam ikatan koordinat.

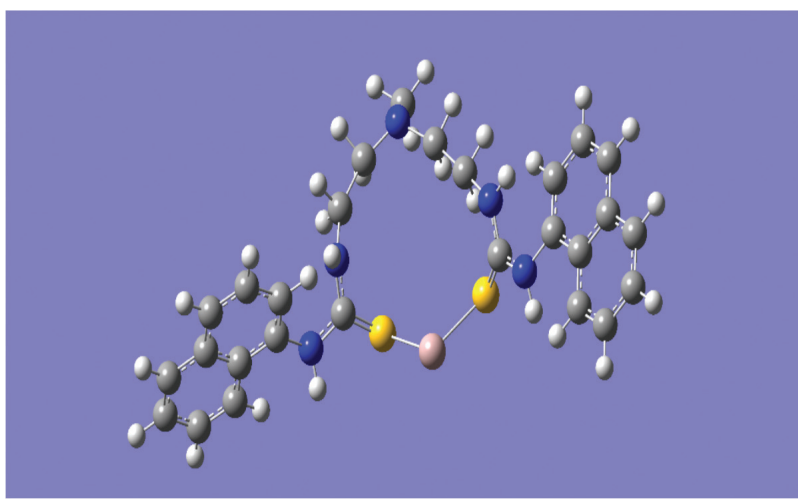

RAJAH 5. Struktur geometri bagi ion kompleks $[\mathrm{Al}(\mathrm{ACH})]^{3+}$ yang telah dioptimumkan

JADUAL 2. Jenis tenaga atomik unit

\begin{tabular}{lc}
\hline Jenis tenaga atomik unit, E & $\mathrm{kJ} / \mathrm{mol}\left(\times 10^{6}\right)$ \\
\hline Aluminium & -0.008 \\
Ligan ACH & -5.556 \\
{$[\mathrm{Al}(\mathrm{ACH})]^{3+}$} & -5.562 \\
Set asas ralat superposisi (BSSE) & -5.562 \\
Pengikatan bagi $[\mathrm{Al}(\mathrm{ACH})]^{3+}$ & -5.560 \\
\hline
\end{tabular}

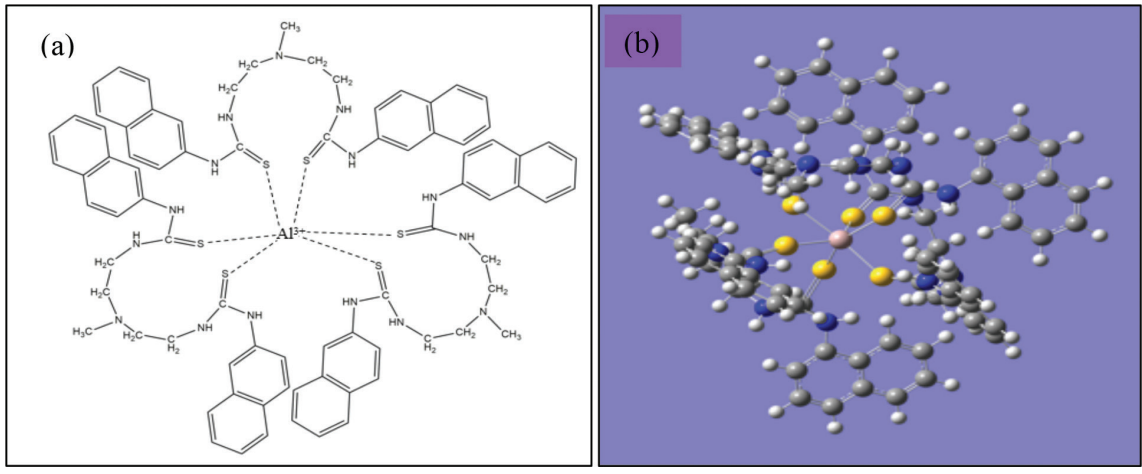

RAJAH 6. Struktur $\left[\mathrm{Al}(\mathrm{ACH})_{3}\right]^{3+}$ yang dicadangkan (a) Model mudah (b) model 3D 


\section{KESIMPULAN}

Sebatian bis-tiourea baru, ACH telah disintesis dan dicirikan melalui analisis spektroskopi. Daripada kajian pengkompleksan, komposisi pelarut $25 \% \mathrm{H}_{2} \mathrm{O}-75 \% \mathrm{EtOH}$ telah berjaya menunjukkan terbentuknya ion kompleks $\left[\mathrm{Al}(\mathrm{ACH})_{3}\right]^{3+}$. Kegagalan penghasilan bagi komposisi pelarut yang lain adalah disebabkan oleh nisbah $\mathrm{H}_{2} \mathrm{O}$ yang tinggi, terbentuknya ikatan hidrogen antara $\mathrm{H}_{2} \mathrm{O}$ dengan ligan $\mathrm{ACH}$ dan pembentukan sebatian-sebatian EtOH-AlCl . Kajian juga mendapati bahawa sedikit $\mathrm{H}_{2} \mathrm{O}$ adalah diperlukan untuk pembentukan ion kompleks $\left[\mathrm{Al}(\mathrm{ACH})_{3}\right]^{3+}$. Nilai $\mathrm{pK}$ yang diperoleh bagi $\left[\mathrm{Al}(\mathrm{ACH})_{3}\right]^{3+}$ ialah 5.10 \pm 0.01 dan kedua-dua sulfur atom pada kumpulan berfungsi tiourea daripada ligan ACH merupakan tapak aktif untuk pengkompleksan. Kesemua hasil keputusan telah menentusahkan kesesuaian sebatian ACH sebagai ionofor aluminium baharu bagi reka bentuk sensor ion potensiometri.

\section{PENGHARGAAN}

Penghargaan terima kasih dirakamkan kepada pihak Universiti Kebangsaan Malaysia untuk sokongan melalui kumpulan penyelidikan, iaitu FRGS/1/2018/STG01/ UKM/02/14 dan dana UP-5179-2017. Terima kasih juga kepada Kementerian Pengajian Tinggi atas pemberian biasiswa MyBrainSc kepada penulis Kook Shih Ying.

\section{RUJUKAN}

Abdullahi, A.A., Choudhury, I.A., Azuddin, M. \& Nahar, N. 2017. Effect of mixing process parameters and suitability of backbone polymer for aluminum powder injection molding feedstock. Sains Malaysiana 46(3): 477-483.

Al-kindy, S.M.Z., Al-hinai, A., Al-rasbi, N.K., Suliman, F.E.O. \& Al-lawati, H.J. 2015. Spectrofluorimetric determination of aluminium in water samples using $\mathrm{N}-((2$-hydroxynaphthalen-1-yl)methylene) acetylhydrazide. Journal of Taibah University for Science 9(4): 601-609.

Bakó, I. \& Mayer, I. 2016. On dipole moments and hydrogen bond identification in water clusters. Journal of Physical Chemistry A 120(25): 4408-4417.

Carmalt, C.J., Mileham, J.D., White, A.J.P., Williams, D.J. \& Rushworth, S. 2003. Synthetic and structural studies on aluminium thiolate complexes. Polyhedron 22(18): 26552660 .

Dennington, R., Keith,T. \& Millam, J. 2016. Gauss View. Version 5. Semichem Inc., Shawnee Mission.

Doroshenko, A.O. \& Pivovarenko, V.G. 2003. Fluorescence quenching of the ketocyanine dyes in polar solvents: AntiTICT behavior. Journal of Photochemistry and Photobiology A: Chemistry 156: 55-64.

Fakhar, I. \& Hasbullah, S.A. 2018. Synthesis and binding behaviour of new isomers of bis-thiourea. Sains Malaysiana 47(6): 1199-1208.

Fakhar, I., Yamin, B.M. \& Hasbullah, S.A. 2017. A comparative study of the metal binding behavior of alanine based bisthiourea isomers. Chemistry Central Journal 11(1): 1-16.

Faridbod, F., Ganjali, M.R., Dinarvand, R. \& Norouzi, P. 2008. Schiff's bases and crown ethers as supramolecular sensing materials in the construction of potentiometric membrane Sensors. Sensors 8: 1645-1703.

Ghanei-motlagh, M., Fayazi, M. \& Taher, M.A. 2014. On the potentiometric response of mercury (II) membrane sensors based on symmetrical thiourea derivatives - Experimental and theoretical approaches. Sensors \& Actuators: B. Chemical 199: 133-141.

Granadero, D., Bordello, J., Perez-Alvite, M.J., Novo, M. \& Al-Soufi, W. 2010. Host-guest complexation studied by fluorescence correlation spectroscopy: Adamantanecyclodextrin inclusion. International Journal of Molecular Sciences 11(1): 173-188.

Herbich, J., Waluk, J., Thummel, R.P. \& Hung, C.Y. 1994 Mechanisms of fluorescence quenching by hydrogen bonding in various aza aromatics. Journal of Photochemistry and Photobiology A: Chemistry 80: 157-160.

Jumal, J., Yamin, B.M., Ahmad, M. \& Lee, Y.H. 2012. Mercury ion-selective electrode with self-plasticizing poly(n-buthylacrylate) membrane based on 1,2-bis-(N'benzoylthiourei-do)cyclohexane as ionophore. APCBEE Procedia 3(May): 116-123.

Kaur, H., Chhibber, M. \& Mittal, S. 2017. Acyclic arylaminebased ionophores as potentiometric sensors for $\mathrm{Zn}^{2+}$ and $\mathrm{Ni}^{2+}$ ions. Journal of Carbon Research 3(4): 1-13.

Khairi. 2016. New thiourea compounds as ionophores for potentiometric sensors of $\mathrm{H}_{2} \mathrm{PO}_{4}^{-}$and $\mathrm{Hg}^{2+}$. Ph.D. Thesis. Faculty Sciences and Technology. Universiti Kebangsaan Malaysia (Tidak diterbitkan).

Kolusheva, T., Hristova, M. \& Costadinnova, L. 2012. Study of the complex formation reaction between $\mathrm{Al}(\mathrm{III})$ and tannic acid. Journal of University of Chemical Technology and Metallurgy 47(5): 570-573.

Kook, S.Y. 2019. Potentiometric ion sensor based on new bisthiourea compound in the determination of aluminium. Ph.D. Thesis. Faculty Sciences and Technology. Universiti Kebangsaan Malaysia (Tidak diterbitkan).

Kook, S.Y., Lee, Y.H., Hassan, N.I. \& Hasbullah, S.A. 2018. A new copper ionophore $\mathrm{N}^{1}, \mathrm{~N}^{3}$-bis[[3,5-bis(trifluoromethyl) phenyl]carbamothioyl]isophtalamide for potentiometric sensor. Sains Malaysiana 47(11): 2657-2666.

Lakowicz, J.R. 1983. Effects of solvents on fluorescence emission spectra. In Principles of Fluorescence Spectroscopy. Boston: Springer. pp. 187-215.

Lazo, A.R., Bustamante, M., Jimenez, J., Arada, M.A. \& YazdaniPedram, M. 2006. Preparation and study of a 1-furoyl-3,3diethylthiourea electrode. Journal of the Chilean Chemical Society 51: 975-978.

Li, Y., Chai, Y., Yuan, R., Liang, W., Zhang, L. \& Ye, G. 2008 Aluminium(III)-selective electrode based on a newly synthesized glyoxal-bis-thiosemicarbazone Schiff base. Journal of Analytical Chemistry 63(11): 1090-1093.

Misra, A., Shahid, M. \& Dwivedi, P. 2009. An efficient thioureabased colorimetric chemosensor for naked-eye recognition of fluoride and acetate anions: UV-vis and 1HNMR studies. Talanta 80(2): 532-538.

Motlagh, M.G., Taher, M.A. \& Ali, A. 2010. PVC membrane and coated graphite potentiometric sensors based on 1-phenyl-3pyridin-2-yl-thiourea for selective determination of iron (III). Electrochimica Acta 55(22): 6724-6730.

Payehghadr, M. \& Ebrahim, S. 2017. Solvent effect on complexation reactions. Journal of Inclusion Phenomena and Macrocyclic Chemistry 89(3): 253-271. 
Pérez, M.D.L.A.A., Yanes, S.L. \& Cardona, M. 2010. Copper(II) selective electrodes based on 1-furoyl-3,3'-diethylthiourea as a neutral carrier. Journal of the Chilean Chemical Society 3: 371-373.

Person, A., Moncomble, A. \& Cornard, J.P. 2014. The complexation of $\mathrm{Al}^{\mathrm{III}}, \mathrm{Pb}^{\mathrm{II}}$, and $\mathrm{Cu}^{\mathrm{II}}$ metal ions by esculetin: $\mathrm{A}$ spectroscopic and theoretical approach. Journal of Physical Chemistry A 118(14): 2646-2655.

Poléo, A.B.S. 1995. Aluminum polymerization - A mechanism of acute toxicity of aqueous aluminum to fish. Aquatic Toxicology 31(4): 347-356.

Rana, S., Mittal, S., Singh, N., Singh, J. \& Banks, C. 2016. Schiff base modified screen printed electrode for selective determination of aluminium (III) at trace level. Sensors \& Actuators: B. Chemical 239: 17-27.

Reichardt, C. 1994. Solvatochromic dyes as solvent polarity indicators. Chemical Reviews 94(8): 2319-2358.

Reinhoudt, D.N. 1992. Molecular Materials for the Transduction of Chemical Information into Electronic Signals by Chemical Field-Effect Transistors. Netherland: American Chemical Society.

Saeed, A., Flörke, U. \& Erben, M.F. 2014. A review on the chemistry, coordination, structure and biological properties of 1-(acyl/aroyl)-3-(substituted) thioureas. Journal of Sulfur Chemistry 35(3): 318-355.

Siswanta, D., Wulandari, Y.D. \& Jumina, J. 2016. Synthesis of poly(benzyleugenol) and its application as an ionophore for a potassium ion-selective electrode. Eurasian Journal of Analytical Chemistry 11(3): 115-125.

Starnes, W.H., Frantz, S. \& Chung, H.T. 1997. Aluminum chloride [alias its reaction product(s) with ethanol] for the stabilization of poly(vinyl chloride)? Polymer Degradation and Stability 56(1): 103-108.

Stewart, H.H. 2002. Binding of proflavin to chymotrypsin: an experiment to determine protein-ligand interactions by direct nonlinear regression analysis of spectroscopic titration data. Biochemical Education 27(2): 118-121.

Suhud, K., Lee, Y.H., Rezayi, M., Al-Abbasi, A.A., Hasbullah, S.A., Ahmad, M. \& Kassim, M.B. 2015. Conductometric studies of the thermodynamics for complexation of 1,1-diethyl-3-(4-methoxybenzoyl)thiourea and cobalt(II) cation in aqueous binary mixtures of polar organic solvents. Journal of Solution Chemistry 44(2): 181-192.

Supian, S.M., Lee, Y.H., Tan, L.L. \& Chong, K.F. 2013. Quantitative determination of $\mathrm{Al}$ (III) ion by using Alizarin Red S including its microspheres optical sensing material analytical methods. Analytical Methods 5: 2602-2609.

Tahir, S.M.,Al-Abbasi,A., Ghazali, Q., Arifin, K. \& Kassim, M.B. 2018. Synthesis, structure and spectroscopic properties of oxovanadium tris(3,5-dimethylpyrazolyl)borate aroylthiourea complexes. Sains Malaysiana 47(8): 1775-1785.
Tajik, S., Taher, M.A. \& Sheikhshoaie, I. 2013. Potentiometric determination of trace amounts of aluminium utilizing polyvinyl chloride membrane and coated platinum sensors based on E-N'-(2-Hydroxy-3-methoxybenzylidene) benzohydrazide. Journal of AOAC International 96(1): 204-211.

Ullah, H., Shah, A.U.H.A., Bilal, S. \& Ayub, K. 2013.DFT study of polyaniline $\mathrm{NH}_{3}, \mathrm{CO}_{2}$, and $\mathrm{CO}$ gas sensors: Comparison with recent experimental data. Journal of Physical Chemistry $C$ 117(45): 23701-23711.

Vallejos, S., Muñoz, A., Ibeas, S., Serna, F., García, F.C. \& García, J.M. 2014. Selective and sensitive detection of aluminium ions in water via fluorescence "turn-on" with both solid and water soluble sensory polymer substrates. Journal of Hazardous Materials 276: 52-57.

Vandana, B. 2018. Resonance. Supramolecular Chemistry 23: 277-290.

Wilson, D., Ángeles, M.D.L. \& Alegret, S. 2010. Lead (II) ion selective electrodes with PVC membranes based on two bis-thioureas as ionophores: 1,3-bis(N-benzoylthioureido)benzene and 1,3-bis(N-furoylthioureido)benzene. Journal of Hazardous Materials 181(1-3): 140-146.

Yan, Z., Wang, H., Xu, C., Wen, X. \& Gu, B. 2014. Preparation of a new aluminum (III) selective electrode based on a hydrazone-containing benzimidazole derivative as a neutral carrier. Journal of Molecular Liquids 190: 185-189.

Zhang, Z., Lu, S., Sha, C. \& Xu, D. 2015. A single thioureaappended 1,8-naphthalimide chemosensor for three heavy metal ions: $\mathrm{Fe}^{3+}, \mathrm{Pb}^{2+}$, and $\mathrm{Hg}^{2+}$. Sensors and Actuators, $B$ : Chemical 208: 258-266.

Centre for Advanced Materials \& Renewable Resources Faculty of Science and Technology

Universiti Kebangsaan Malaysia

43600 UKM Bangi, Selangor Darul Ehsan

Malaysia

*Corresponding author; email: aishah80@ukm.edu.my

Received: 15 July 2019

Accepted: 25 September 2019 
LAMPIRAN 1

Kesan Komposisi Pelarut $\mathrm{H}_{2} \mathrm{O}-\mathrm{ETOH}$ yang Berbeza terhadap Spektrum Pemancaran Ion Kompleks $\mathrm{ACH}^{-\mathrm{Al}^{3}}$

(a) $99 \% \mathrm{H}_{2} \mathrm{O}-1 \% \mathrm{EtOH}$

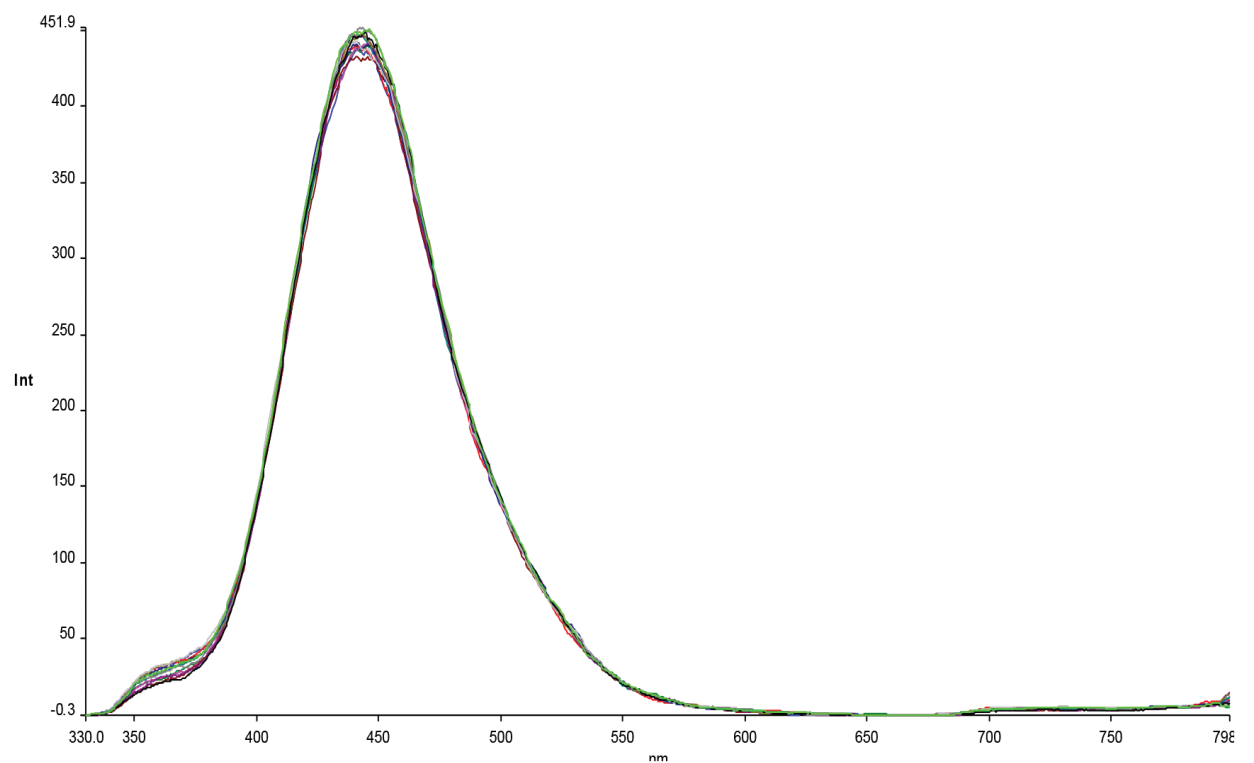

(b) $75 \% \mathrm{H}_{2} \mathrm{O}-25 \% \mathrm{EtOH}$

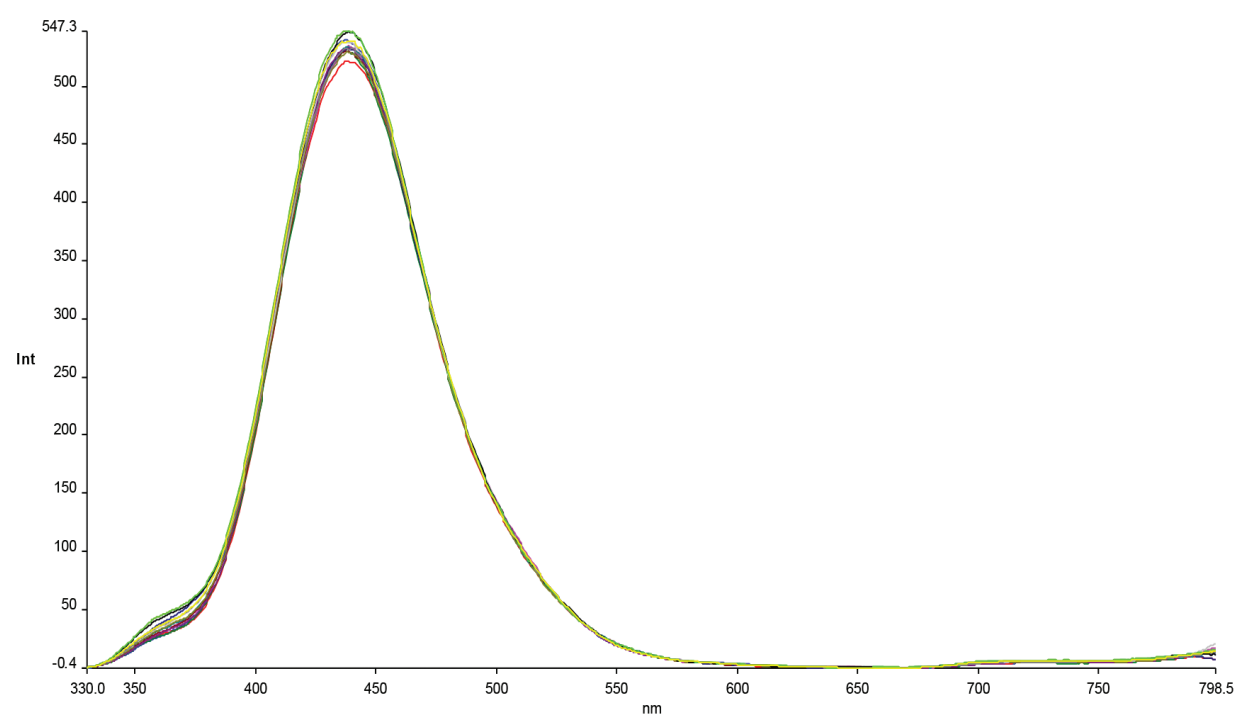


2660

(c) $50 \% \mathrm{H}_{2} \mathrm{O}-50 \% \mathrm{EtOH}$

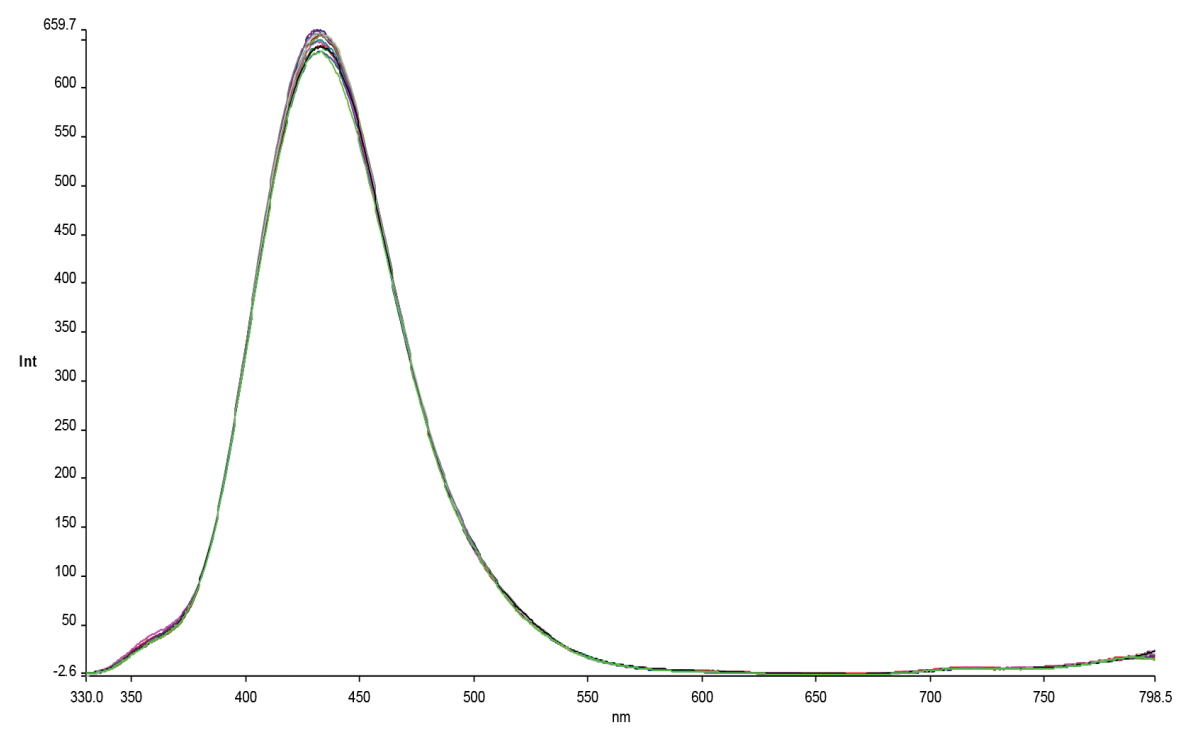

(d) $25 \% \mathrm{H}_{2} \mathrm{O}-75 \% \mathrm{EtOH}$
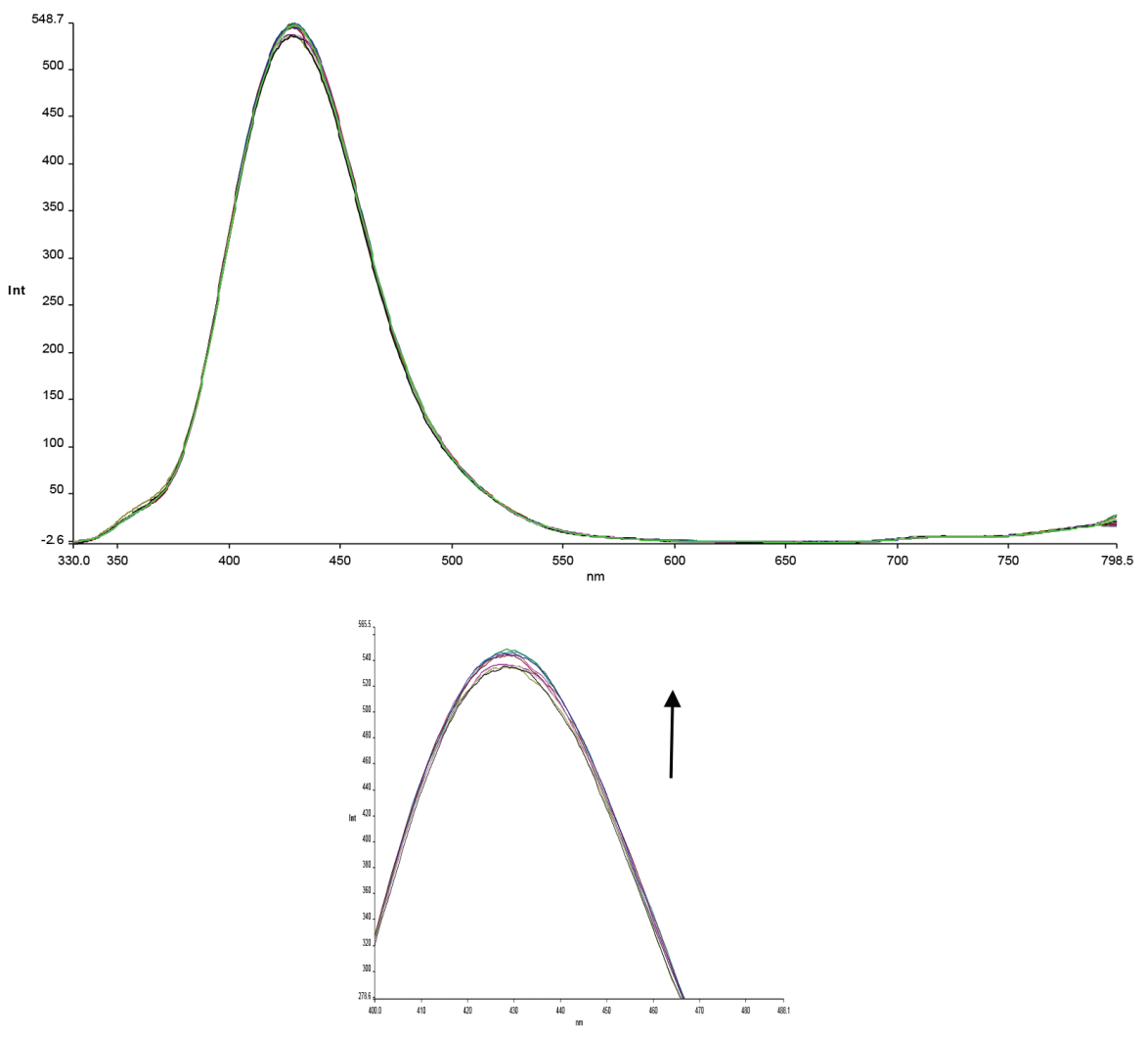
(e) $0 \% \mathrm{H}_{2} \mathrm{O}-100 \% \mathrm{EtOH}$

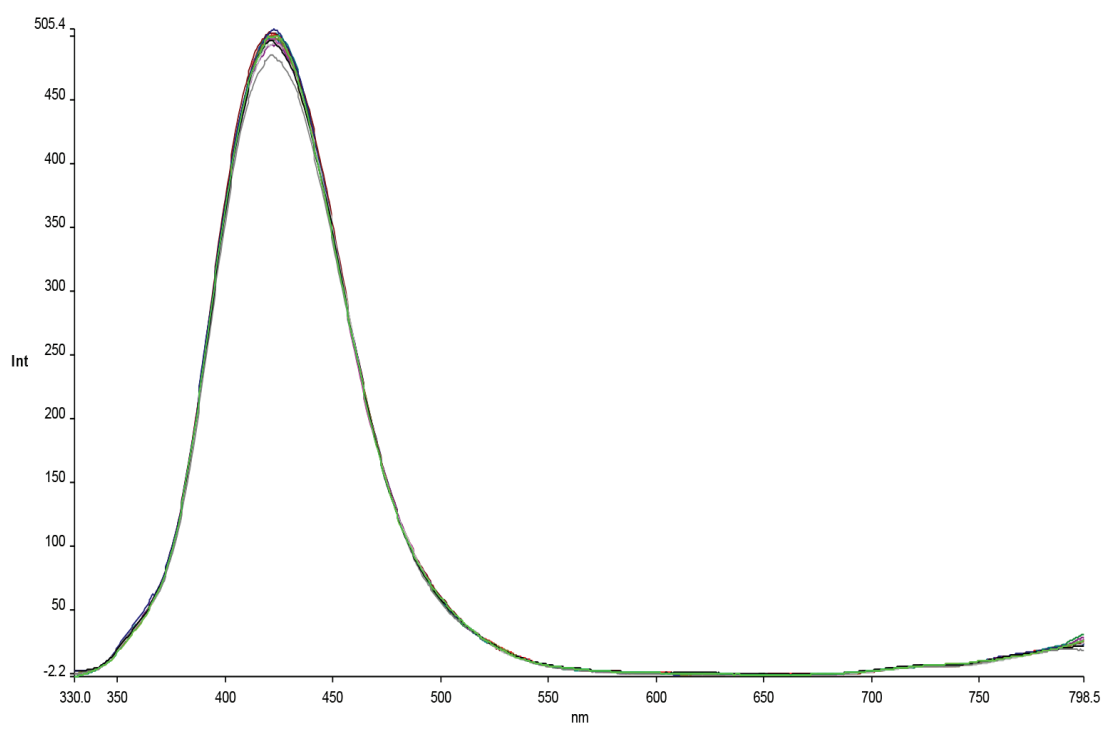

